\title{
SALINITAS OPTIMAL UNTUK PENDEDERAN BENIH IKAN BETUTU (Oxyeleotris marmorata)
}

\author{
Idil Ardi*\#, Eri Setiadi*), Anang Hari Kristanto**), dan Ani Widiyati*| \\ *) Balai Penelitian dan Pengembangan Budidaya Ikan Hias \\ *) Balai Penelitian dan Pengembangan Budidaya Air Tawar
}

\begin{abstract}
ABSTRAK
Ikan betutu (Oxyeleotris marmorata) termasuk ikan perairan tawar yang memiliki nilai ekonomis penting dan sangat disukai karena memiliki daging yang tebal, tulangnya sedikit, dan gurih. Salah satu faktor lingkungan yang berpengaruh dalam kegiatan budidaya adalah salinitas. Penelitian bertujuan untuk mendapatkan salinitas optimum dalam pemeliharaan benih ikan betutu yang diharapkan dapat meningkatkan sintasan dan pertumbuhannya. Penelitian menggunakan rancangan acak lengkap (RAL) dengan empat perlakukan berdasarkan perbedaan salinitas yaitu kontrol ppt, 1 ppt, 3 ppt, dan 5 ppt. Setiap perlakuan dilakukan tiga kali pengulangan. Hasil penelitian menunjukkan terdapat perbedaan nyata $(P<0,05)$ terhadap laju pertumbuhan spesifik, panjang mutlak, bobot mutlak, dan kadar glukosa darah terhadap kontrol (salinitas 0 ppt) setelah dipelihara selama 56 hari. Laju pertumbuhan mutlak, bobot mutlak, dan glukosa darah paling baik dijumpai pada benih yang dipelihara dengan salinitas $3 \mathrm{ppt}$, yaitu $0,94 \pm 0,09 \% 2,53 \pm 0,35$ $\mathrm{mm} ; 37,33 \pm 6,28 \mathrm{~g}$; dan $0,06 \pm 0,01 \mathrm{~g} / \mathrm{dL}$. Pemeliharaan benih betutu membutuhkan air bersalinitas. Untuk mengoptimalkan pertumbuhan dan sintasan air media budidaya disarankan bersalinitas 3 ppt.
\end{abstract}

\section{KATA KUNCl: salinitas; benih; betutu}

ABSTRACT: Optimizing salinity for sand goby (Oxyeleotris marmoratus) seedling reared. By: Idil Ardi, Eri Setiadi, Anang Hari Kristanto, and Ani Widiyati

Sand goby (Oxyeleotris marmorata) is one of freshwater fish that has high economic value and is more desired for its thick meat, bone less, and tasteful. Salinity is one of the most important environmental factors in fish culture. The purpose of this study was to determine the optimal salinity concentration on growth and survival of sand goby fish. A completely Randomized Design (CRD) was used in this study with four treatments of salinity levels comprising A) Control; B) 1 ppt; C) 3 ppt; D) 5 ppt. Each treatment was consisted of three replicates. The result showed significant differences $(P<0.05)$ in specific growth rate, absolute length, absolute weight, and blood glucose among the treatments against control after 56 days cultured. Seed reared under the salinity of $3 \mathrm{ppt}$ was better than other treatmentsin terms of specific growth rate $(0.94 \pm 0.09 \%$, absolute length $(2.53 \pm 0.35 \mathrm{~mm})$, absolute weight $(37.3 \pm 6.28 \mathrm{mg})$, and blood glucose $(0.06 \pm 0.01 \mathrm{~g} / \mathrm{dl})$. Based on the present result, it was suggested that $3 \mathrm{ppt}$ of salinity is better for optimize the growth and survival of sand goby.

\section{KEYWORDS: salinity; juvenile; sand goby fish; aquaculture}

\section{PENDAHULUAN}

Ikan betutu, Oxyeleotris marmorata (Blkr.) merupakan ikan komoditas budidaya air tawar yang sangat diminati oleh masyarakat Indonesia, sehingga memiliki nilai ekonomis yang tinggi. Harga ikan betutu dapat mencapai Rp 60.000,00 per kilogram di tengkulak menjadi peluang yang besar untuk usaha budidaya perikanan. Ikan ini memiliki rasa daging yang lezat,

\footnotetext{
\# Korespondensi: Balai Penelitian dan Pengembangan Budidaya Ikan Hias. Jl. Perikanan No. 13, Pancoran Mas, Depok 16436, Jawa Barat, Indonesia. Tel. + (021) 7520482 E-mail: ardiidil@yahoo.com
}

dengan tekstur yang lembut, dan berwarna putih. Daging ikan betutu mengandung sedikit kolesterol, protein $(9 \% 22 \%$, lemak $(0,1 \% 20 \%$, mineral $(1 \% 3 \%$, vitamin, lecithin, dan guanin (Arief et al., 2009).

Ikan betutu tidak hanya menjadi komoditas lokal, namun juga sebagai salah satu komoditas ekspor yang selalu dicari terutama oleh negara Singapura, Malaysia, dan Hongkong dengan harga yang cukup tinggi. Spesies ikan betutu ini tersebar di Thailand, Laos, Kamboja, Vietnam, Brunei, Malaysia, dan Indonesia. Di wilayah Indonesia ikan ini tersebar di Pulau Kalimantan, Sumatera, dan Jawa. Umumnya pembudidaya mendapatkan benih dari alam. 
Kelestarian ikan betutu di alam mulai terganggu karena benih untuk suplai budidaya merupakan hasil tangkapan dari alam. Produksi benih yang kontinu dapat menjadi solusi menjaga kelestarian ikan betutu di alam dan kelangsungan budidayanya. Teknologi budidaya benih betutu yang berkesinambungan diharapkan dapat mendukung kelestarian ikan betutu. Usaha produksi benih melalui budidaya masih terkendala dengan tingkat sintasan yang rendah, pertumbuhan yang lambat dan masih sulit disediakan pakan alami pada stadia larva. Permasalahan yang dihadapi dalam memelihara benih ikan betutu sangatlah kompleks. Menurut Ismail (2010), ikan sangat sensitif terhadap perubahan yang terjadi baik bersifat eksternal maupun internal. Pada dasarnya ikan juga sangat cepat merespons segala macam bentuk faktor tersebut untuk tetap mempertahankan homeostasis tubuh sehingga ia tetap bisa bertahan hidup.

Faktor eksternal yang lebih dikenal dengan lingkungan dalam kondisi yang tidak stabil menyebabkan stres pada ikan. Salah satu faktor fisika lingkungan yang berpengaruh adalah salinitas. Salinitas dapat memengaruhi proses biologi dan secara langsung memengaruhi laju pertumbuhan, jumlah makan yang dikonsumsi, nilai konversi makanan, dan daya sintasan. Menurut Syakirin (2007), proses osmoregulasi pada ikan air tawar berfungsi untuk memelihara $\mathrm{Na}^{+}$dan $\mathrm{Cl}^{-}$dalam tubuh ikan dan mempertahankan keseimbanagan asam basa, sehingga fungsi fisiologis organ-organ tubuhnya dapat berjalan normal dan transpor aktif ini akan mengakibatkan terjadinya konservasi energi dalam tubuh ikan. Proses osmoregulasi adalah upaya yang dilakukan hewan akuatik untuk mengontrol keseimbangan air dan ion antara di dalam dan di luar tubuh melalui mekanisme pengaturan tekanan osmotik (Setyadi et al., 1997). Habitat ikan betutu dijumpai dari perairan tawar seperti sungai, danau, dan rawa, bahkan hingga ke perairan payau seperti muara sungai (Kottelat et al., 1993).

Beberapa hasil penelitian pemeliharaan benih ikan air tawar dapat berkembang dengan baik pada salinitas optimum, seperti benih ikan gurame pada salinitas optimum 3 ppt dengan sintasan $92,27 \%$ dan laju pertumbuhan spesifik $0,49 \pm 0,07 \%$ (Dewi, 2006), benih ikan sinodontis pada salinitas optimum 4 ppt dengan sintasan 100\%dan laju pertumbuhan spesifik $2 \pm 0,31 \%$ (Gustino, 2011) dan benih ikan tengadak mempunyai salinitas optimum 4 ppt dengan sintasan $90 \%$ dan laju pertumbuhan spesifik 1,65\%(Nurjanah, 2014). Pada ikan Carassius auratus dan Carassius carassius pertumbuhan (SGR) paling baik pada salinitas 12 ppt, yaitu 0,34 \pm 00,95 dan 0,30 $\pm 0,103 \%$ (Kucuk,
2013). Pemeliharaan larva ikan betutu pada stadia larva dari umur tiga hari setelah menetas hingga 40 hari setelah menetas membutuhkan salintas optimal 10 ppt, namun setelah 40 hari menetas diduga bahwa benih ikan betutu dapat dipelihara pada air tawar maupun air payau (Senoo et al., 2008). Hal ini menunjukkan bahwa belum adanya informasi salinitas optimal untuk pemeliharaan benih ikan betutu dari 40 hari setelah menetas. Untuk itu, perlu dilakukan penelitian pengaruh sal initas pada pemeliharaan benih ikan betutu.

Salinitas merupakan salah satu parameter lingkungan yang sangat relevan hubungannya dengan kecernaan pakan dan pertumbuhan ikan (Darwis et al., 2009). Upaya perbaikan lingkungan dengan perlakuan salinitas terhadap pemeliharaan benih ikan betutu diharapkan dapat meningkatkan pertumbuhannya, karena perlakuan salinitas mampu meningkatkan efisiensi penggunaan energi dalam proses osmoregulasi. Tujuan penelitian untuk mendapatkan salinitas optimum dalam pemeliharaan benih ikan betutu yang diharapkan dapat meningkatkan sintasan dan pertumbuhannya.

\section{BAHAN DAN METODE}

\section{Waktu dan Tempat Penelitian}

Penelitian ini dilakukan pada bulan SeptemberOktober 2015, di Instalasi Penelitian dan Pengembangan Budidaya Ikan, Lingkungan dan Toksikologi, Cibalagung-Bogor.

Sebanyak 12 buah wadah plastik bervolume 20 liter $(47 \mathrm{~cm} \times 31 \mathrm{~cm} \times 26 \mathrm{~cm}$ ) sebagai wadah uji yang dilengkapi dengan aerasi. Benih betutu diperoleh dari Parung, Bogor dengan ukuran panjang total 1,20 \pm $0,23 \mathrm{~cm}$ dan bobot $0,053 \pm 0,029 \mathrm{~g}$. Padat tebar sebanyak lima ekor per liter (100 ekor per wadah). Benih ikan diberi pakan Artemia dengan kepadatan 99 ekor/mL yang diberikan dua kali per hari (pukul 08:00 dan 16:00). Untuk membuat konsentrasi salinitas sesuai dengan perlakuan, air tawar dicampur dengan air laut berdasarkan prosuder persamaan Hukom (2007), yaitu:

$$
\mathrm{Va} \cdot \mathrm{Na}=\mathrm{V}_{1} \cdot \mathrm{N}_{1}+\mathrm{V}_{2} \cdot \mathrm{N}_{2}
$$

di mana:

$V a=$ volume akhir air yang dikehendaki (L)

$\mathrm{Na}=$ tingkat salinitas akhir air yang dikehendaki (ppt)

$\mathrm{V}_{1}=$ volume air laut yang diencerkan (L)

$\mathrm{N}_{1}=$ tingkat salinitas air laut yang diencerkan (ppt)

$\mathrm{V}_{2}=$ volume air taw ar yang ditambahkan (L)

$\mathrm{N}_{2}=$ tingkat salinitas air tawar yang ditambahkan (ppt)

Rancangan penelitian adalah rancangan acak lengkap (RAL) dengan empat perlakuan dan setiap 
perlakuan diulang sebanyak tiga kali. Perlakuan yang diujikan adalah:

- Perlakuan A (kontrol): ikan betutu dipelihara pada media bersalinitas $0 \mathrm{ppt}$

- Perlakuan B: ikan betutu dipelihara pada media bersalinitas $1 \mathrm{ppt}$

- Perlakuan C: ikan betutu dipelihara pada media bersalinitas 3 ppt

- Perlakuan D: ikan betutu dipelihara pada media bersalinitas 5 ppt

Sampling ikan dilakukan setiap tujuh hari sekali dengan cara menimbang bobot dan mengukur panjang benih ikan betutu dengan sampling lima ekor per ulangan, serta digunakan untuk uji kadar glukosa pada plasma tubuh ikan.

\section{Laju Pertumbuhan Spesifik (LPS)}

Laju pertumbuhan spesifik dihitung dengan rumus (Huisman, 1987):

$$
\text { LPS }=\left[\mathrm{t} \sqrt{\frac{\mathrm{Wt}}{\mathrm{W}_{0}}}-1\right] \times 100 \%
$$

di mana:

LPS $=$ laju pertumbuhan spesifik $(\%)$

$\mathrm{Wt}=$ bobot rata-rata pada akhir perlakuan $(\mathrm{g})$

$W_{0}=$ bobot rata-rata pada awal perlakuan (g)

$\mathrm{t}=$ periode pemeliharaan (hari)

\section{Pertumbuhan Bobot Mutlak}

Pertumbuhan bobot mutlak dihitung dengan rumus (Zonneveld et al., 1991):

$$
\mathrm{W}=\mathrm{Wt}-\mathrm{Wo}_{0}
$$

di mana:

$\mathrm{W}=$ pertumbuhan bobot mutlak $(\mathrm{g})$

$W \mathrm{t}=$ bobot rata-rata ikan pada akhir perlakuan $(\mathrm{g})$

$W_{0}=$ bobot rata-rata ikan pada awal perlakuan (g)

\section{Pertumbuhan Panjang Mutlak}

Pertumbuhan panjang mutlak dihitung dengan rumus (Zonneveld et al., 1991):

$$
\mathrm{L}=\mathrm{Lt}-\mathrm{LO}
$$

di mana:

$\mathrm{L}=$ pertumbuhan panjang mutlak $(\mathrm{cm})$

Lt $=$ panjang rata-rata ikan pada akhir perlakuan $(\mathrm{cm})$

$L_{0}=$ panjang rata-rata ikan pada awal perlakuan $(\mathrm{cm})$

\section{Kadar Glukosa Plasma Tubuh}

Pengukuran kadar glukosa plasma tubuh dilakukan pada awal dan akhir percobaan dengan menggunakan Metode Blood Glucose Test (Eames et al., 2010).

Pengukuran parameter kualitas air oksigen terlarut (Disolved Oxygen= DO) menggunakan alat water checker merek Hanna. Sedangkan parameter kualitas air nitrit, nitrat, TAN, dan fosfat dianalisis berdasarkan SNI. Pengukuran parameter kualitas air tersebut dilakukan setiap tujuh hari sekali.

Data yang diperoleh, ditabulasi, dan dianalisis sidik ragam (ANOVA) pada selang kepercayaan 95\% menggunakan program Microsoft Excel 2010 dan SPSS16.0. Apabila berpengaruh nyata dilakukan uji lanjut Duncan. Kualitas air dianalisis secara deskriptif.

\section{HASIL DAN BAHASAN}

\section{Performansi Pertumbuhan Ikan}

Benih ikan betutu setelah dipelihara selama 56 hari laju pertumbuhan spesifik pada perlakuan C (3 ppt) sebesar 0,94\% lebih baik dari perlakuan A (kontrol) sebesar $0,74 \%$ B (1 ppt) sebesar 0,39\% dan D (5 ppt) sebesar $0,48 \%$ (Gambar 1). Uji statistik menunjukkan nilai laju pertumbuhan spesifik pada semua perlakuan menunjukkan hasil yang berbeda nyata terhadap kontrol (salinitas 0 ppt) $(P<0,05)$.

Pertumbuhan panjang mutlak benih ikan betutu setelah dipelihara selama 56 hari dapat dilihat pada Gambar 2, terlihat bahwa perlakuan C (3 ppt) pertumbuhan panjang mutlak sebesar $2,53 \mathrm{~mm}$ lebih baik dari perlakuan $A$ (kontrol) sebesar $1,60 \mathrm{~mm}$; perlakuan B (1 ppt) sebesar 1,00 mm; dan perlakuan D (5 ppt) sebesar 1,53 mm. Uji statistik diperoleh bahwa nilai pertumbuhan panjang mutlak pada perlakuan $\mathrm{C}$ menunjukkan hasil yang berbeda nyata $(P<0,05)$ dengan perlakuan $A, B$, dan $D$.

Pertumbuhan bobot mutlak benih ikan betutu setelah dipelihara selama 56 hari (Gambar 3), menunjukkan bahwa perlakuan C (3 ppt) sebesar 37,3 $\mathrm{mg}$ lebih baik dari perlakuan lainnya yaitu perlakuan $\mathrm{A}$ (kontrol) sebesar $18 \mathrm{mg}, \mathrm{D}$ (5 ppt) sebesar $18 \mathrm{mg}$, dan B (1 ppt) sebesar 15,3 mg. Uji statistik, nilai pertumbuhan bobot mutlak benih ikan betutu pada perlakuan $C$ diperoleh hasil yang berbeda nyata $(P<0,05)$ dengan perlakuan $A, B$, dan $D$.

Hasil penelitian pemeliharaan benih ikan betutu pada salinitas yang berbeda menunjukkan pertumbuhan yang berbeda. Pertumbuhan benih 


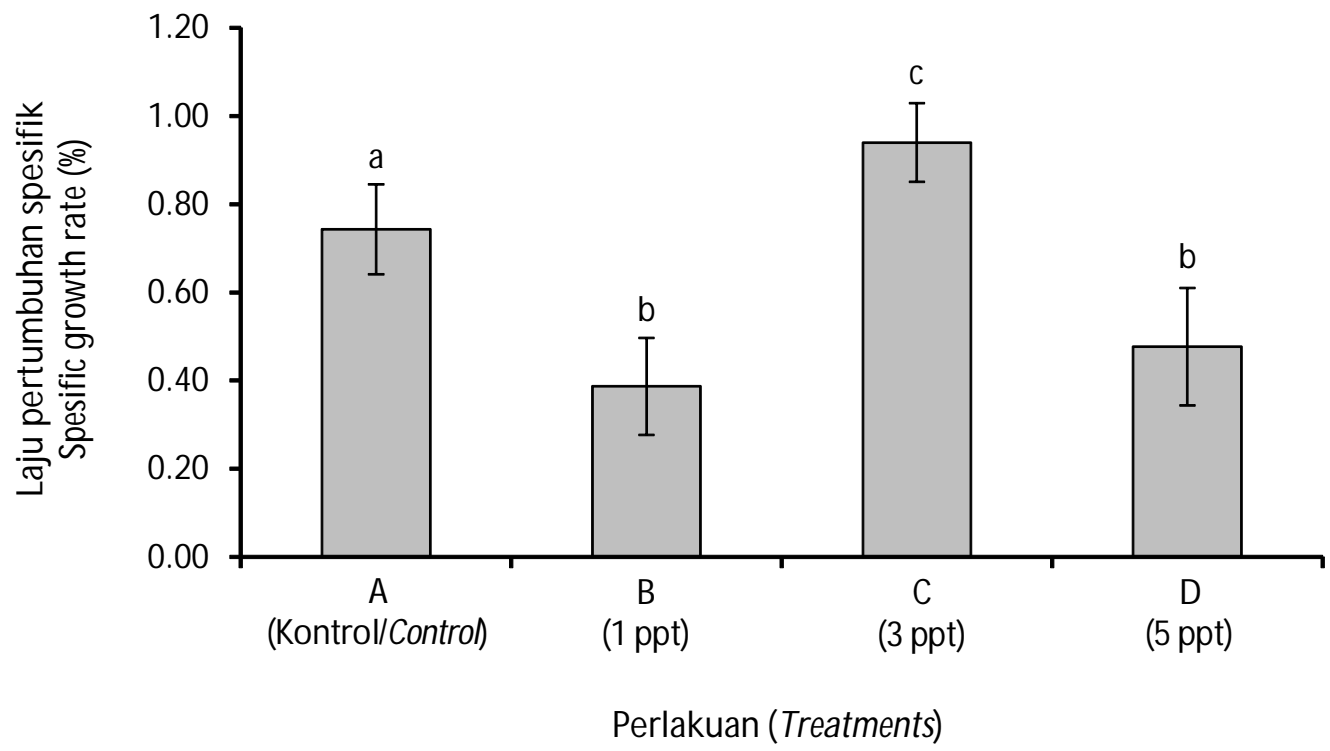

Gambar 1. Laju pertumbuhan spesifik benih ikan betutu (Bars yang diikuti dengan huruf yang sama menunjukkan tidak berbeda nyata $(P>0,05))$

Figure 1. Spesific growth rate of sand goby juvenile (Bars followed with the same letters indicated no significantly different $(P>0.05))$

betutu terlihat perbedaannya dengan perlakuan lainnya berdasarkan laju pertumbuhan panjang mutlak, dan pertumbuhan bobot mutlak. Hal ini mengindikasikan bahwa salinitas berpengaruh terhadap pertumbuhan panjang dan bobot mutlak. Menurut Konstantinov \& Martynova (1993), benih ikan betutu sangat membutuhkan air yang asin, meskipun setelah besar hidupnya di air tawar. Jenis ikan air tawar lainnya yang membutuhkan air yang asin, ikan mas (Cyprinus carpio) dalam salinitas 12 ppt pertumbuhan dan sintasan meningkat sangat cepat dan terjadi efisiensi pakan (Jelkic et al., 2014). Benih ikan belanak (Mugilidae) dapat berkembang dengan baik pada kisaran salinitas optimum 0-5 ppt (El-Dahhar et al., 2000).

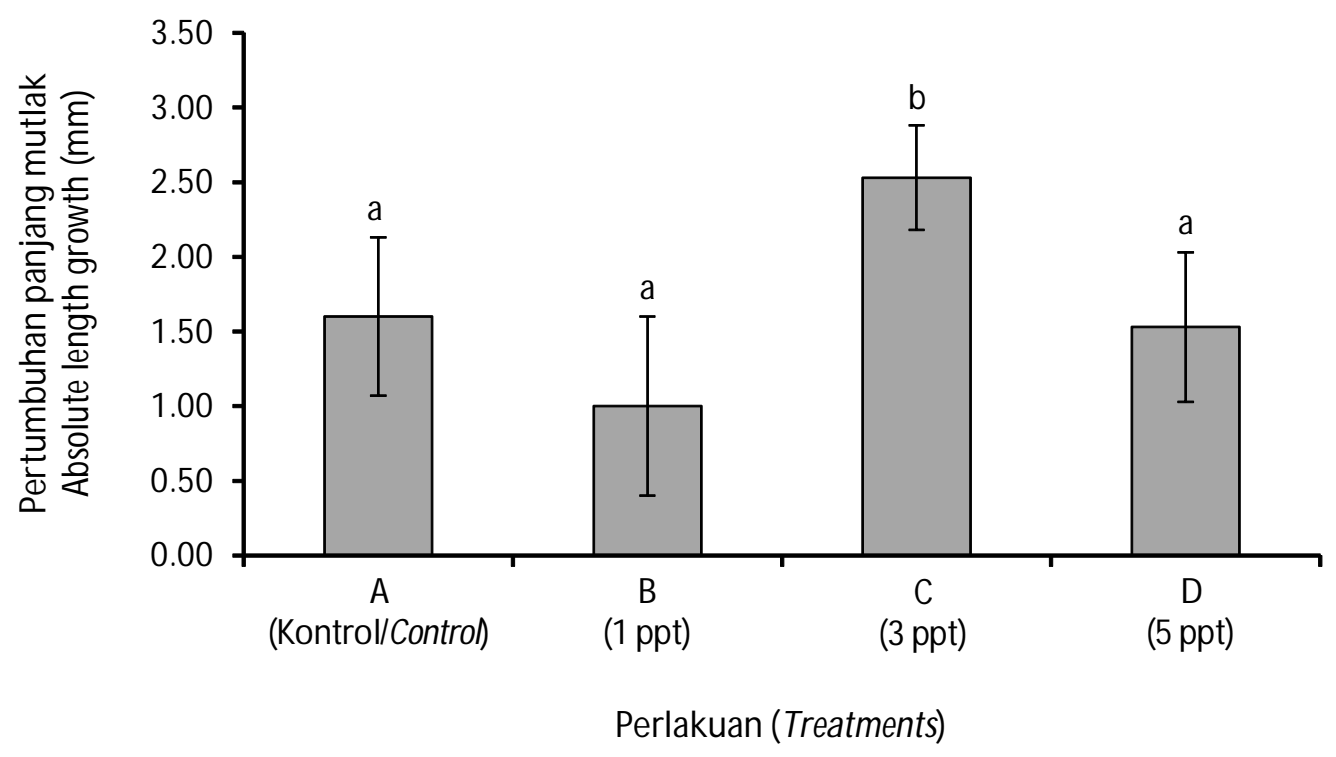

Gambar 2. Pertumbuhan panjang mutlak benih ikan betutu (Bars diikuti dengan huruf yang sama menunjukkan tidak berbeda nyata $(P>0,05))$

Figure 2. Absolut growth in length of sand goby juvenile (Bars followed with the same letters indicated no significantly different $(P>0.05))$ 


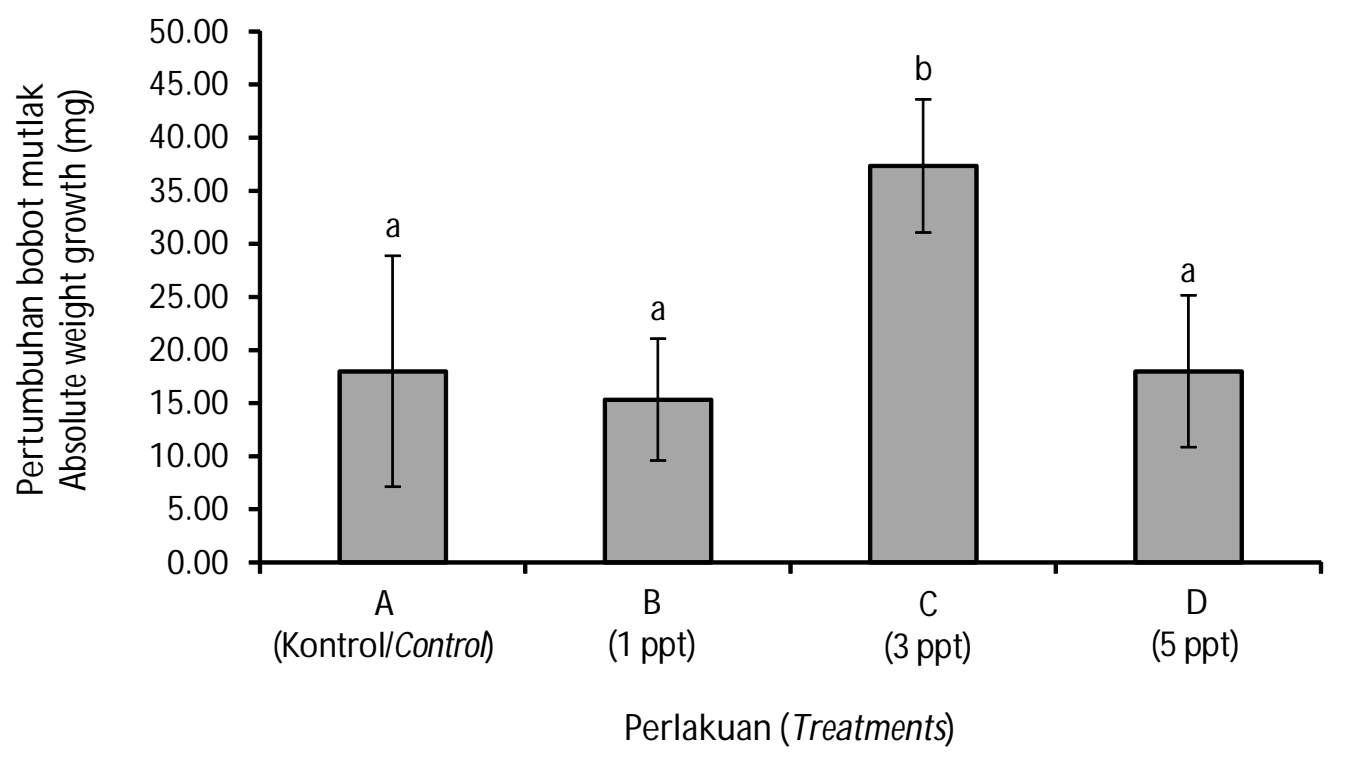

Gambar 3. Pertumbuhan bobot mutlak benih ikan betutu (Bars diikuti dengan huruf sama menunjukkan tidak berbeda nyata $(P>0,05))$

Figure 3. Absolut growth in weight for sand goby juvenile (Bars followed with the same letters indicated no significantly different $(P>0.05))$

Berdasarkan perbedaan salinitas terlihat bahwa benih ikan betutu mempunyai batas toleransi terhadap perbedaan salinitas di lingkungan tempat hidupnya dalam kisaran salinitas yang sempit. Hasil penelitian menunjukkan perlakuan $\mathrm{C}$ dengan salinitas 3 ppt menghasilkan pertambahan panjang mutlak dan bobot mutlak benih betutu lebih cepat dibanding pemeliharaan benih pada salinitas 0 ppt, 1 ppt, dan 5 ppt (Gambar 1-3). Hal ini diduga bahwa kondisi perairan salinitas 3 ppt merupakan kondisi ideal bagi benih betutu untuk menyesuaikan keseimbangan antara osmotik internal iso osmotik (sama) dan kondisi osmotik eksternal, sehingga energi tidak banyak dihabiskan untuk osmoregulasi dan lebih banyak dipakai untuk pertumbuhan. Menurut Syakirin (2007), pada saat sel-sel tubuh ikan berada dalam kondisi yang seimbang antara tekanan osmotik intemal dengan tekanan osmotik eksternal, maka sel-sel organ tubuh dapat berfungsi dengan baik untuk melakukan proses fisiologis. Salinitas berpengaruh terhadap proses fisiologis aktivitas hormon, yaitu hormone gonadothropin, cortisol, insulin pertumbuhan, dan tyroid (McCormik, 2001). Hal ini diduga berkaitan erat dengan pertumbuhan bahwa hasil penelitian pada benih ikan betutu dengan salinitas 3 ppt diperoleh pertumbuhan yang paling baik dibandingkan dengan perlakuan lainnya. Kucuk (2013) menyatakan bahwa bila konsentrasi salinitas tinggi ataupun rendah dapat menyebabkan stres yang dapat memengaruhi tiga dimensi, yaitu respons utama, sistem saraf simpatetik akan menstimulir melepas catecholamine dan plasma cortisol. Respons sekunder, aktivitas hormon akan melepas glukosa ke dalam darah untuk produksi energi pada detak jantung, aliran darah, dan laju metabolisme. Respons tertier perubahan pada fisiologis darah yang menyebabkan terjadinya pertumbuhan lambat.

\section{Kadar Glukosa Darah}

Pada perlakuan A (kontrol) dan B (1 ppt) salinitas lingkungan perairan yang lebih rendah sehingga pertumbuhan benih betutu lebih lambat dibandingkan perlakuan C (3 ppt) dan perlakuan D (5 ppt) diduga akibat ikan mendapat stressor lingkungan menyebabkan ikan mengalami stres. Berdasarkan hasil uji kadar glukosa darah pada perlakuan A (kontrol) dan B (1 ppt) tinggi masing-masing $0,78 \pm 0,11 \mathrm{~g} / \mathrm{dL}$ dan $0,68 \pm$ $0,07 \mathrm{~g} / \mathrm{dL}$; kemudian diikuti perlakuan $\mathrm{D}(5 \mathrm{ppt})$ sebesar $0,17 \pm 0,06 \mathrm{~g} / \mathrm{dL}$ dan terendah pada perlakuan C (3 ppt) yaitu 0,06 $\pm 0,01 \mathrm{~g} / \mathrm{dL}$ (Gambar 4). Statistik menunjukkan bahwa perlakuan $C$ berbeda nyata dengan perlakuan $A, B$, dan $D(P<0,05)$.

Kadar glukosa darah yang tinggi pada perlakuan A dan B menunjukkan benih ikan betutu dalam kondisi stres diduga akibat adanya perbedaan salinitas sehingga menggangu keseimbangan osmotik di dalam tubuh ikan. Ikan yang stres menyebabkan hiperglisemia (meningkatnya kadar glukosa darah), yang dapat mengganggu pertumbuhan selanjutnya bahkan dapat mematikan (Hastuti et al., 2003). 


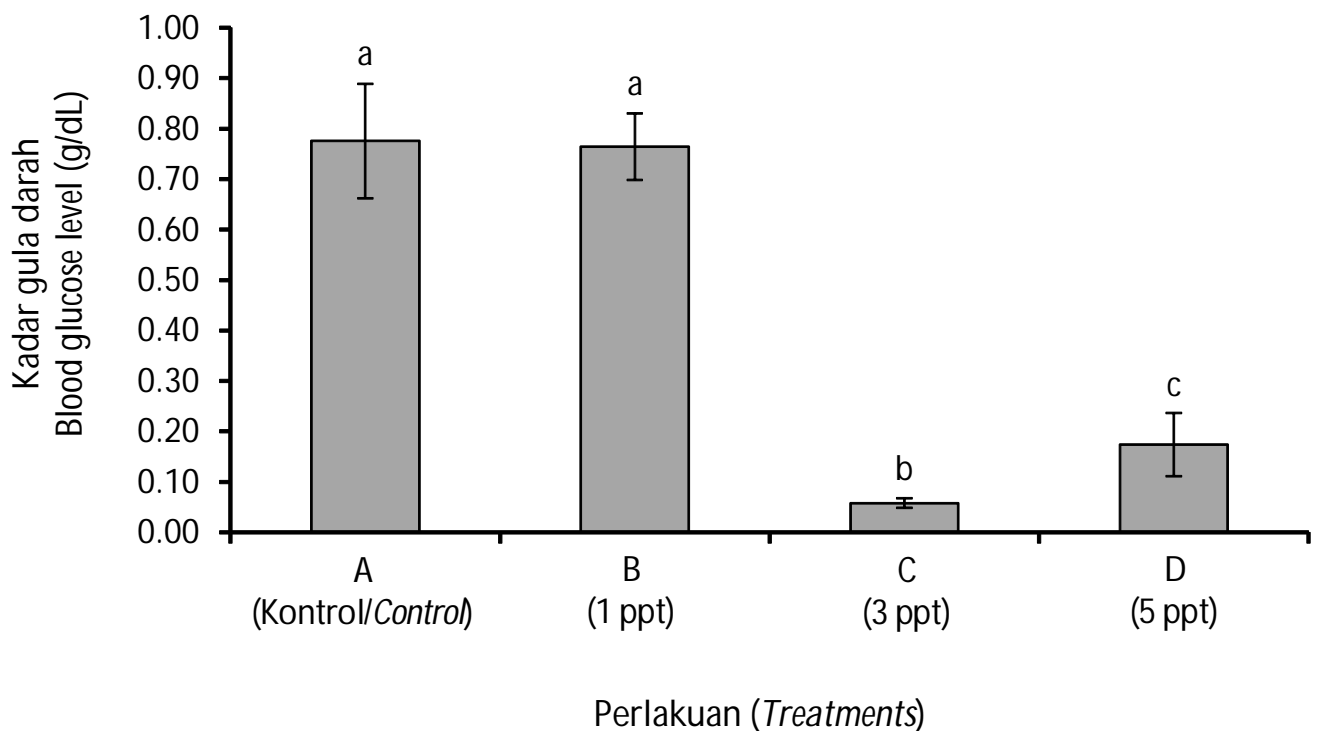

Gambar 4. Kadar glukosa dalam darah (Bars diikuti dengan huruf sama tidak berbeda nyata $(P>0,05)$

Figure 4. Blood glucose level (Bars followed with the same letters indicated no significantly different $(P>0.05))$

Menurut Royan (2014), pada saat ikan stres menyebabkan kadar glukosa dalam darah terus naik yang diperlukan untuk mengatasi homeostasis dan insulin akan menurun. Selanjutnya, Anderson (1990) menjelaskan pada saat ikan mengalami gangguan yang menyebabkan stres, baik karena penanganan, kualitas air maupun infeksi bakteri, maka tubuh ikan akan mengeluarkan tanda sebagai indikasi adanya gangguan. Tanda pada ikan tersebut di antaranya pertama, adanya peningkatan gula darah akibat sekresi hormon dari kelenjar adrenalin. Persediaan gula, seperti glikogen dalam hati dimetabolisme sebagai persediaan energi untuk emergensi. Kedua, osmoregulasi akibat perubahan metabolisme mineral. Ikan air tawar cenderung mengabsorbsi air dari lingkungan (over-hydrate), ikan air laut cenderung kehilangan air dari dalam tubuh. Kondisi ini perlu energi ekstra untuk memelihara keseimbangan osmoregulasi. Ketiga, pernafasan meningkat, tensi darah meningkat, persediaan eritrosit di-release ke sistem resirkulasi dan keempat, respons inflamasi ditekan oleh hormon dari kelenjar adrenalin.

Tingkat glukosa darah benih ikan betutu pada perlakuan $\mathrm{A}$ dan $\mathrm{B}$ yang tinggi mengindikasikan ikan menjaga keseimbangan osmotiknya pada kondisi salinitas di lingkungan rendah. Demikian pula sebaliknya pada perlakuan $D$ kadar glukosa darah benih betutu sedikit lebih tinggi dibanding perlakuan $C$, karena benih betutu berada dalam kondisi lingkungan dengan tingkat salinitas yang tinggi.
Penyesuaian kesimbangan osmotik (kadar garam) di lingkungan yang lebih rendah dari dalam tubuh ikan seperti pada perlakuan A dan B, maka proses osmoregulasi dilakukan dengan cara sedikit minum air dan banyak membuangnya melalui urine. Demikian halnya pada perlakuan D (5 ppt), kondisi osmotik lingkungan diduga lebih tinggi dari dalam tubuh ikan sehingga cenderung masuk ke dalam cairan tubuh ikan. Kadar garam di dalam tubuh ikan yang tinggi berupaya untuk membuangnya melalui urine dengan banyak minum air. Royce (1984) mengatakan bahwa sebagian besar organisme akuatik akan mempertahankan air dan garam dalam tubuhnya pada proporsi yang konstan. Syakirin (2007) menjelaskan kelebihan air diekskresikan sebagai urine yang sangat encer dan dapat dihasilkan dalam jumlah sampai sepertiga dari bobot badan per hari. Perbedaan tekanan osmose yang semakin jauh antara tubuh dan lingkungan, semakin banyak energi metabolisme yang dibutuhkan untuk melakukan osmoregulasi sebagai upaya adaptasi, namun tetap ada batas toleransi. Menurut Arjona et al. (2009), banyaknya energi yang digunakan untuk mempertahankan kondisi homeostatis menyebabkan menurunnya nafsu makan ikan akibat terjadinya respons terhadap perubahan lingkungan. Hal ini membuktikan bahwa perlakuan $C$ salinitas 3 ppt benih ikan betutu diduga berada pada kondisi keseimbangan osmotik antara di dalam tubuh dengan lingkungannya, sehingga ikan tidak stres dan tidak banyak energi yang dihabiskan untuk melakukan proses osmoregulasi. 
Dengan kata lain benih ikan betutu sebagian besar energinya digunakan untuk pertumbuhan. Benih ikan betutu pada perlakuan C (3 ppt) tumbuh lebih cepat dibanding perlakuan lainnya dengan laju pertumbuhan spesifik $94 \%$ pertumbuhan panjang mutlak $2,53 \mathrm{~mm}$; dan pertumbuhan bobot mutlak $37,3 \mathrm{mg}$.

\section{Kondisi Kualitas Air}

Hasil pengukuran parameter kualitas air seperti oksigen terlarut (DO), nitrit $\left(\mathrm{NO}_{2}-\mathrm{N}\right)$, nitrat $\left(\mathrm{NO}_{3}-\mathrm{N}\right)$, total amonia (TAN), dan fosfat $\left(\mathrm{PO}_{4}-\mathrm{P}\right)$ pada media pemeliharaan benih ikan betutu setiap perlakuan selama pemeliharaan 56 hari dapat dilihat pada Tabel 1.

Konsentrasi oksigen terlarut (DO) nilai kisarannya masih dalam batas yang layak menurut standar baku untuk budidaya perikanan (Tabel 1). Hal yang sama, konsentrasi nitrat $\left(\mathrm{NO}_{3}\right)$ yang terdapat dalam media pemeliharaan benih betutu masih dalam kisaran yang tidak terlalu tinggi. Konsentrasi nitrat masih di bawah standar baku kelayakan budidaya.

Konsentrasi fosfat pada semua perlakuan sudah cukup tinggi melebihi ambang batas standar baku budidaya. Meskipun fosfat tidak toksik bagi ikan, tapi dapat menyebabkan pertumbuhan fitoplankton di kolam dan badan perairan (sungai dan danau). Konsentrasi fosfat yang telah melebihi ambang batas standar baku diduga berasal dari sisa pakan dan metabolisme ikan yang terdapat di media pemeliharaan. Pakan yang diberikan adalah Artemia yang merupakan pakan hidup yang tidak bisa bertahan hidup lama dalam media pemeliharaan ikan.

Konsentrasi nitrit $\left(\mathrm{NO}_{2}\right)$ dan total amonia (TAN) dal am media air pemeliharaan benih ikan betutu sudah melebihi standar baku untuk kelayakan budidaya ikan (Tabel 1). Menurut standar baku konsentrasi nitrit dalam media air budidaya tidak boleh melebihi konsentrasi 0,06 mg/L. Konsentrasi nitrit dan TAN yang tinggi membahayakan bagi sintasan benih ikan karena bersifat racun (Kroupova et al., 2005; Karasubenlu \& Koksal, 2005). Konsentrasi nirit dan TAN terlihat semakin meningkat sejalan dengan peningkatan kadar salinitas. Tinggginya kandungan nitrit dan TAN pada media pemeliharaan diduga berasal dari metabolisme ikan (feses dan urine). Hal ini diduga berkaitan dengan kondisi osmoregulasi yang dilakukan oleh ikan dalam mempertahankan keseimbangan kondisi osmotik. Pada salinitas perairan lingkungannya lebih tinggi maka ikan akan sedikit minum air dan akan banyak mengeluarkan ion dalam bentuk amonia melalui urine ke lingkungan.

Konsentrasi amonia di atas angka 0,02 mg/L dapat menyebabkan timbulnya keracunan pada ikan bila kondisi kronis yang berlangsung dalam waktu yang lama menyebabkan rusaknya jaringan insang, sedangkan konsentrasi amonia yang tinggi (di atas 0,3 mg/L) akan mempercepat rusaknya insang, sehingga menyulitkan pengambilan oksigen (Karasubenlu \& Koksal, 2005).

\section{KESIMPULAN}

Pemeliharaan benih betutu memerlukan media yang bersalinitas, media bersalitas dapat mengurangi tingkat stres sehingga dapat meningkatkan pertumbuhannya. Pertumbuhan terbaik ikan ini pada salinitas 3 ppt.

\section{UCAPAN TERIMA KASIH}

Ucapan terima kasih disampaikan pada Balai Penelitian dan Pengembangan Budidaya Air Tawar, Bogor yang telah mendanai kegiatan ini melalui anggaran APBN Tahun 2015.

Tabel 1. Nilai rata-rata dan standar deviasi kualitas air

Table 1. Avarage and deviation standard of water quality values

\begin{tabular}{|c|c|c|c|c|c|}
\hline \multirow{2}{*}{$\begin{array}{l}\text { Parameter } \\
\text { Parameters }\end{array}$} & \multicolumn{4}{|c|}{ Perlakuan salinitas (Salinity treatments ) } & \multirow{2}{*}{$\begin{array}{l}\text { Standar baku } \\
\text { Standards }\end{array}$} \\
\hline & $\begin{array}{c}\text { A } \\
\text { (kontrol/control) }\end{array}$ & $\begin{array}{c}\text { B } \\
\text { (1 ppt) }\end{array}$ & $\begin{array}{c}\text { C } \\
\text { (3 ppt) }\end{array}$ & $\begin{array}{c}\text { D } \\
\text { (5 ppt) }\end{array}$ & \\
\hline $\mathrm{DO}(\mathrm{mg} / \mathrm{L})$ & $3.88 \pm 0.44$ & $3.66 \pm 0.40$ & $3.66 \pm 0.32$ & $3.58 \pm 0.47$ & 4 \\
\hline $\mathrm{NO}_{2}(\mathrm{mg} / \mathrm{L})$ & $0.07 \pm 0.02$ & $0.06 \pm 0.03$ & $0.68 \pm 0.68$ & $1.15 \pm 0.78$ & 0.06 \\
\hline $\mathrm{NO}_{3}(\mathrm{mg} / \mathrm{L})$ & $1.29 \pm 0.44$ & $1.38 \pm 0.79$ & $1.85 \pm 0.81$ & $1.75 \pm 0.78$ & 10 \\
\hline TAN (mg/L) & $0.29 \pm 0.03$ & $0.34 \pm 0.11$ & $0.41 \pm 0.05$ & $0.41 \pm 0.48$ & $\leq 0.02$ \\
\hline $\mathrm{PO}_{4}(\mathrm{mg} / \mathrm{L})$ & $0.85 \pm 0.54$ & $0.64 \pm 0.35$ & $0.60 \pm 0.34$ & $0.55 \pm 0.31$ & 0.2 \\
\hline
\end{tabular}

Keterangan (Note): * Standar baku kualitas air kelas II PP No. 82 tahun 2001 


\section{DAFTAR ACUAN}

Anderson, D.P. (1990). Immunological indicators: effects of environmental stress on immune protection and disease outbreaks. American Fisheries Society Syposium, (8), 38-50.

Arief, M., Triasih, I., \& Lokapirnasih, W.P. (2009). Pengaruh pemberian pakan alami dan pakan buatan terhadap pertumbuhan benih ikan betutu (Oxyeleotris marmorata Bleeker). Jurnal IImiah Perikanan dan Kelautan, 1, 57-60.

Arjona, J.F., Chacoff , L.V., Jarabo, I.R., Goncalves, O., Pascoa, I., Maria, P., Rio, M.D., \& Mancera, J.M. (2009). Tertiary stress responses in Senegalese sole (Solea senegalensis Kamp. 1858) to osmotic challenge: Implication for osmoregulation, energy metabolism, and growth. Aquaculture, 2287, 419426.

Darwis, M., Shaleh, S.R.M., \& Senoo, S. (2009). Daily food intake, feeding activity and growth of marble goby, Oxyeleotris marmoratus juveniles reared under different salinity levels. Aquaculture Sci., 57(2), 185-191.

Dewi, E.S. (2006). Pengaruh salinitas 0, 3, 6, 9, dan 12 ppt terhadap pertumbuhan dan sintasan benih ikan gurame (Osphronemus goramy) ukuran 3-6 cm. Skripsi. Institut Pertanian Bogor. Bogor (ID).

Eames, S.C., Philipson, L.H., Prince, V.E., \& Kinkel, M.D. (2010). Blood sugar measurement in zebrafish reveals dynamics of glucose homeostasis. Zebrafish, 7(2), 205-213.

El-Dahhar, A.A., Salama, M., M ousta, Y., \& Zahran, S. (2000). Effect of salinity and salinity acclimatization on survival and growth of the wild hatched mullet larvae using different feeds in glass aquaria. Egypt J. Aqua Biol. \& Fisic., 4(2), 137-155.

Gustino, R.T. (2011). Kinerja pertumbuhan ikan sinodontis (Synodontis eupterus) pada media pemeliharaan bersalinitas. Skripsi. Institut Pertanian Bogor. Bogor (ID).

Hastuti, S., Supriyono, E., Mokoginta, I., \& Subandiyono. (2003). Respon glukosa darah ikan gurami (Osphronemus gouramy, LAC.) terhadap stres perubahan suhu lingkungan. Jurnal Akuakultur Indonesia, 2(2), 73-77.

Huisman, E.A. (1987). The principles of fish culture production. Departemen of Aquaculture. Wageningen University. Netherland (NL).

Hukom, V. (2007). Pengaruh salinitas dan kesadahan terhadap tingkat sintasan, tingkat konsumsi oksigen, dan osmolaritas udang vanname (Litopenaeus vannamei). Skripsi. Institut Pertanian Bogor. Bogor (ID).
Ismail, K. (2010). Kiat mengatasi stres pada ikan. Mediatama. Jakarta, $68 \mathrm{hlm}$.

Jelkic, D., Opacak, A., Horvat, D., \& Safner, R. (2014). Common carp fry survival during salinity stress test: effect of feeding regime. Veterinarski Arhiv., 84(4), 429-438.

Karasubenlu, A.C., \& Koksal, G.I.K. (2005). The acute toxicity of ammonia on tilapia (Oreochromis niloticus L.) larvae and fingerlings. Turk. J. Vet. Anim. Sci., 29, 339-344.

Konstantinov, A.S., \& Martynova, V.V. (1993). Effect of salinity fluctuations on energetics of juvenile fish. J. Ichthyol., 33, 161-166.

Kottelat, M., Whiten, A.J., Kartikasari, S.N., \& Wirjoatmodjo. (1993). Freshwater fishes of Western Indonesia and Sulawesi. Periplus Edition. Hong Kong, 221 pp.

Kroupova, H., Machova, J., \& Svobodova, Z. (2005). Nitrite influence on fish: a review. Vet. M ed.-Czech., 50(11), 461-471.

Kucuk, S. (2013). The effects of salinity on growth of goldfish, Carassius auratus and crucian carp, Carassius carassius. African Journal of Biotechnology, 12(6), 2082-2087.

McCormik. (2001). Endocrine control of osmoregulation in teleost fish. Am. Zool., 41, 781-179.

Nurjanah, S.K. (2014). Optimalisasi salinitas untuk sintasan dan pertumbuhan benih ikan tengadak (Barbonymus schwanenfeldii Bleeker). Skripsi. Institut Pertanian Bogor. Bogor (ID).

Royce, W.F. (1984). Introduction to The Practice of Fisheries Science. Academic press. New York.

Royan, F. (2014). Pengaruh Salinitas yang Berbeda Terhadap Profil Darah Ikan Nila (Oreochromis niloticus). Skripsi. Undip. Semarang.

Senoo, S., Sow, H.S., \& Mukai, Y. (2008). Effects if different salinity levels on the survivals and growth of marble goby, Oxyeleotris marmoratus larvae. Aquaculture Sci., 56(3), 423-432.

Setyadi, I., Azwar, Z.I., Yunus, \& Kasprijo. (1997). Penggunaan jenis pakan alami dan pakan buatan dalam pemeliharaan larva kepiting bakau (Scylla serrata). J. Pen. Perik. Indonesia, hIm 73-77. ISSN: 0853-6384.

Syakirin, M.B. (2007). Mekanisme pompa natrium kalium $\left(\mathrm{Na}^{+}-\mathrm{K}^{+}\right)$pada osmoregulasi ikan bertulang sejati (Teleost). Jurnal Pena Akuatika, 1(1), 24-33.

Zonneveld, N., Huisman, E.A., \& Boon, J.H. (1991). Prinsip-prinsip budidaya ikan. Gramedia Pustaka Utama. Jakarta, $318 \mathrm{hlm}$. 